\title{
Low birth weight in a subnormal urban cluster under Family Health Strategy's care
}

Maria de Fátima Caminha 1

iD https://orcid.org/0000-0003-0653-5324

Camila Carvalho Santos 2

iD https://orcid.org/0000-0002-3770-4162

Suzanna Lins da Silva 3

https://orcid.org/0000-0001-9783-0737

Tacyanne Fischer Lustosa 4

https://orcid.org/0000-0002-3635-3030

Luana Cristina Queiroz Farias 5

(iD) https://orcid.org/0000-0002-5870-7813

\author{
Janaína Natália Alves Lima 6 \\ (iD) https://orcid.org/0000-0001-5450-128X \\ Malaquias Batista Filho 7 \\ (iD) https://orcid.org/0000-0002-1490-0590
}

1,2,7 Instituto de Medicina Integral Prof. Fernando Figueira. Rua dos Coelhos, 300. Boa Vista. Recife, PE, Brasil. CEP: 50.070-902. E-mail: camilacarvalhoupe@gmail.com 3,4,5,6 Faculdade Pernambucana de Saúde. Recife, PE, Brasil.

\begin{abstract}
Objectives: to identify the prevalence and to analyze the factors associated with low birth weight in a subnormal urban cluster in Pernambuco under Family Health Strategy's care.

Methods: a cross-sectional study with a census sample carried out between July and October in 2015. The variables studied were age and years of maternal schooling, social status, housing, water supply, waste disposal, prenatal care, alcohol consumption and cigarette smoking during pregnancy, along with gender, birth weight and prematurity. Stata 12.1 was utilized in order to understand the factors associated with low birth weight through uniand-multivariate Poisson analysis, adjusted and gross prevalence ratios, composing a final statistical model considering $p$ value $<0.05$ for statistical significance.

Results: regarding the 294 children the LBW prevalence was $12.2 \%(C I 95 \%=8.7-16.5)$. Children whose mothers reported drinking during pregnancy were 2.78 times more at risk of being born with low birth weight $(p<0.001)$ when compared with children whose mothers did not report this practice in gestation.

Conclusions: the study evidenced the relevance maternal habits bears in the newborns' health.

Key words Low birth weight, Prevalence, Primary health care
\end{abstract}




\section{Introduction}

Birth weight represents an important indicator of intrauterine conditions to which a child is subjected during the gestation period.1,2 It is considered an important predictor of survival probability for newborns in the short term; of the physiological development of a child in the medium term; and of an adult's health in the long term, increasing the risk of developing chronic, non-transmissible diseases. ${ }^{3-5}$

According to the United Nations (UN), the rate of low birth weight (LBW) is $16 \%$ on a world scale and $9 \%$ in Brazil, 6 and is influenced by assistential, environmental and socioeconomic conditions that the mother experienced in the gestation period.7-19 Thus, the following risk factors to LBW emerge: poverty, ${ }^{7-9}$ low educational attainment with consequent lack of information, 10,11 habits in pregnancy such as the consumption of cigarettes 12,13 and alcoholic beverages, 14-16 and assistance in healthcare.1719 It is, in fact, a field open to more consistent studies on the reality of maternal and infant health in Brazil, notably in regard to the populations from subnormal urban clusters. Favelas and other types of precarious settlements, situation defined as 'subnormal urban cluster', 20 therefore constitute the most visible expression of the habitational problems. 21

The accelerated growth of urban populations, in large part related to the migration flow coming from the rural zone, in addition to its impoverishment, repercutes adversely, with social, nutritional, environmental and health consequences, since in general the families have no conditions to afford the demands of the expenses of housing and other equipments of the urban area, and are, therefore, led to use housing settlements in precarious and irregular conditions to reside in the environment. 21

Therefore, a growing number of people start living in slums with limited access to the necessary infrastructure for a healthy life. ${ }^{7}$ Characterized this way over 100 years ago in Brazil, they present their own organizational structures, without a strategic plan of urban occupation, lacking and/or having inadequate basic services (water, sewage, electric power distribution network, institutional network of public schools, healthcare and social assistance services), where habitually the labor market presents a high level of informality and insecurity, and the educational attainment level is low, which then justifies the traditional definition of favela.

In that regard, the present study aims at identifying the prevalence and analyzing the factors associated with low birth weight at a subnormal urban cluster in Pernambuco assisted by the family health strategy (FHS).

\section{Methods}

Cross-sectional study, part of the inquiry "Saúde, nutrição e serviços assistenciais numa população favelada do Recife", 22 with data collection between July and October, 2015, carried out in a subnormal urban cluster in Recife. Adopting census coverage, the inquiry studied all children from 0 to 36 months old who have been registered by Community Health Agents from the two Basic Health Units in the area.

For the current study, variables of interest were selected and an ad hoc database elaborated. LBW $(<2,500 \mathrm{~g})$ was considered as an outcome variable; and the predictor variables corresponded to maternal age $(<20 ; 20$ to 35 and $>36$ years), to maternal years of education ( $>12$ and $<12$ ), to social status (B; C and $\mathrm{D} / \mathrm{E}$ ), to house type (house and stilt house/shanty/room), to water supply plumbing (yes/no), to the destination of waste in the general sewage network (yes/no), to prenatal care attendance (yes/no), to smoking in pregnancy (yes/no), to alcohol consumption in pregnancy (yes/no) and to child gender (female/male). The social status was evaluated following the classification framework developed by the Brazilian Association of Research Companies (ABEP - Portuguese acronym), 23 which considers classes A, B1, B2, C1, C2 and D E, corresponding approximately to the respective average monthly incomes in minimum wages (MW) at 14 MW, 7 MW, 4 MW, $2 \mathrm{MW}, 1.6 \mathrm{MW}$ and $1 \mathrm{MW}$. For analysis purposes, that classification was distributed in three categories: $\mathrm{B} 1 / \mathrm{B} 2=\mathrm{B}, \mathrm{C} 1 / \mathrm{C} 2 /=\mathrm{C}, \mathrm{D}$ and $\mathrm{E}$.

The children with no information on their birth weight were excluded from the database, collected from the Child Health Record Book and, in the absence of it, from the records at the Basic Health Units.

Aposteriori, the Stata Software (Stata Statistical Software: release 12 - Collete Station, TX, United States) was analyzed to calculate whether the collected sample, albeit of census character, had sufficient power to identify any association between the "alcohol consumption in pregnancy" variable and low birth weight, which corresponded to $88.6 \%$ of power.

The categorical variables were presented in tables of absolute and relative frequencies and a confidence interval of $95 \%$. In order to identify the possibly associated factors to the occurence of LBW, set as birth weight at $<2,500 \mathrm{~g}$, simple and multiple Poisson regression models were adjusted, and the 
gross and adjusted prevalence ratios (PR), as well as the respective confidence intervals (CI) of $95 \%$, were estimated. As screeningfor the multivariate analysis, the chosen variables were those which showed a value of $p<0.20$ in the univariate analysis, leaving for the final model those variables with a value of $p<0.05$. The statistical significance of each variable was evaluated by the Wald test.

The inquiry has been approved by the IMIP's Committee for Ethics in Research with human subjects, CAAE no. 07246912.6.0000.5201.

\section{Results}

Out of the 310 children registered in the original research's database, 294 children who had information on their birth weight were part of this study. The prevalence of LBW was $12.2 \%(\mathrm{CI} 95 \%=8.7-16.5)$, which corresponds to 36 out of the 294 children in the study, representing $94.8 \%$ of the reported universe of children aged less than 3 years based in the community. Prematurity occurred in $6.1 \%$ $(18 / 293)$.

Table 1 shows the results found through univariate analysis. The lack of sewage system in the residence $(p=0.047)$, no prenatal care $(p=0.045)$, and alcohol consumption by the mother during pregnancy ( $p=0.001$ ) were statistically significant.

Through multivariate analysis, we found that children whose mothers mentioned alcohol consumption in pregnancy were 2.78 times more at risk of being born with low weight $(p<0.001)$ when compared with children whose mothers did not mention such consumption during gestation (Table 2).

\section{Discussion}

In this study, the prevalence of low birth weight was $12.2 \%$. A significant increase in the risk of LBW was found among children whose mothers mentioned alcohol consumption during pregnancy.

The reference value of $12.2 \%$ represents much lower prevalence than the world statistics (16\%), much higher, however, than the Brazilian average (9\%), although countries with a better standard have reached results between 4 and 5\%.6 Nevertheless, the question remains: would the value of $12.2 \%$ apply to urban communities in the studied region with similar features or, with more effectiveness, to other favela populations in Brazil? In other words, what is the external validity of our results, considering the greater, not only initial, interest in reporting the problem of low weight to an estimate reality of 11 million people, which constitutes the demographic effective size of Brazilian favelas?21 Briefly, we should remember that the LBW is one of the most discriminating indicators for Health's international heterogeneities, exemplified with the cases of South Asia (38\%) and Iemen (32\%), whereas Finland shows $4 \% .6$

The limitation of the descriptive data on the LBW problem in the population from Brazilian favelas anticipates the qualitative and quantitative restrictions imposed on the results analysis in their three aspects: the contributions of the pertinent, current literature; the reliability, which can be questioned, of the sample size (although in this study that is an analysis of census character); and finally, how these results can be perceived in a process of great dynamism, as the quick nutritional transition in Brazil.24

The preliminary data analysis of this study shows that out of the ten groups of exploratory variables which gather factors historically associated with LBW, only 5 (the mothers' low educational attainment, water supply with no domestic canalization, sewage not discharged into to the sewage system, the absence of prenatal care, and alcohol consumption during gestation) denote reasons of gross prevalence near or among the statistical significance values established at a $95 \%$ confidence interval. For the relations adjusted by the Poisson multiple regression, only alcohol consumption remained statistically significant in the final model.

Other studies reported significant association between alcohol consumption during pregnancy and LBW.9,14,25 In Pelotas (RS, Brazil), the risk of LBW was four times higher; 9 in Ribeirão Preto (SP, Brazil), 1.62 time higher; 14 and in Bahia, 7.9 times higher, 25 compared to pregnant women who did not consumed alcohol.

In addition to LBW, literature also shows other complications associated with alcohol consumption in pregnancy, such as abortion, malformation, perinatal mortality, among others. ${ }^{14}$

Evidences demonstrate that the alcohol consumed in pregnancy crosses the placental barrier, which allows the prolonged exposition of the fetus to the ethanol from the amniotic fluid. This substance not only harms the cell divisions but also inhibits the retinoic acid synthesis, an embryonic development regulator, producing negative effects to the fetus development and health, including serious complications as fetal alcohol syndrome. $9,15,16$

Regarding the complications caused by alcohol consumption, and since this habit is still practiced in pregnancy,26,27 we emphasize the importance of 
Factors associated with low birth weight in children aged 0 to 36 months at Basic Health Units in a subnormal urban cluster in Northeastern Brazil, Recife, PE, 2015.

\begin{tabular}{|c|c|c|c|c|c|c|}
\hline \multirow[t]{2}{*}{ Variable } & \multicolumn{2}{|c|}{ Sample* } & \multicolumn{2}{|c|}{ LBW } & \multirow[t]{2}{*}{$\mathrm{PR}^{* *}$ gross $(\mathrm{Cl} 95 \%)$} & \multirow[t]{2}{*}{$p^{* * *}$} \\
\hline & $\mathrm{n}$ & $\%$ & $\mathrm{n}$ & $\%$ & & \\
\hline Maternal age (years) $(N=294)$ & & & & & & 0.619 \\
\hline$<20$ & 49 & 16.7 & 6 & 12.2 & $1.06(0.46-2.45)$ & \\
\hline $20-35$ & 217 & 73.8 & 25 & 11.5 & 1.0 & \\
\hline$\geq 36$ & 28 & 9.5 & 5 & 17.9 & $1.55(0.64-3.73)$ & \\
\hline Maternal years of education $(\mathrm{N}=294)$ & & & & & & 0.059 \\
\hline$\geq 12$ & 109 & 37.1 & 8 & 7.3 & 1.0 & \\
\hline$<12$ & 185 & 62.9 & 28 & 15.1 & $2.06(0.97-4.37)$ & \\
\hline Social status $(\mathrm{N}=294)$ & & & & & & 0.837 \\
\hline B & 14 & 4.8 & 1 & 7.1 & 1.0 & \\
\hline C & 219 & 74.5 & 27 & 12.3 & $1.73(0.25-11.83)$ & \\
\hline $\mathrm{D}$ and $\mathrm{E}$ & 61 & 20.7 & 8 & 13.1 & $1.84(0.25-13.56)$ & \\
\hline Types of houses $(N=294)$ & & & & & & 0.687 \\
\hline House & 236 & 80.3 & 28 & 11.9 & 1.0 & \\
\hline Stilt house/Shanty/Room & 58 & 19.7 & 8 & 13.8 & $1.16(0.56-2.42)$ & \\
\hline Internal water plumbing $(\mathrm{N}=294)$ & & & & & & 0.056 \\
\hline Yes & 218 & 74.1 & 22 & 10.1 & 1.0 & \\
\hline No & 76 & 25.9 & 14 & 18.4 & $1.83(0.98-3.39)$ & \\
\hline \multicolumn{7}{|l|}{ Waste disposed into the general sewage } \\
\hline system $(N=294)$ & & & & & & 0.047 \\
\hline Yes & 176 & 59.9 & 16 & 9.1 & 1.0 & \\
\hline No & 118 & 40.1 & 20 & 16.9 & $1.86(1.01-3.45)$ & \\
\hline Prenatal care attendance $(\mathrm{N}=292)$ & & & & & & 0.045 \\
\hline Yes & 273 & 93.5 & 31 & 11.4 & 1.0 & \\
\hline No & 19 & 6.5 & 5 & 26.3 & $2.32(1.02-5.28)$ & \\
\hline Smoking in pregnancy $(\mathrm{N}=292)$ & & & & & & 0.514 \\
\hline Yes & 55 & 18.8 & 8 & 14.5 & $1.28(0.61-2.66)$ & \\
\hline No & 237 & 81.2 & 27 & 11.4 & 1.0 & \\
\hline \multicolumn{3}{|c|}{ Alcohol consumption in pregnancy $(N=291)$} & & & & 0.001 \\
\hline Yes & 74 & 25.4 & 17 & 23.0 & $2.77(1.51-5.09)$ & \\
\hline No & 217 & 74.6 & 18 & 8.3 & 1.0 & \\
\hline Child gender $(N=294)$ & & & & & & 0.148 \\
\hline Male & 148 & 50.3 & 14 & 9.5 & 1.0 & \\
\hline Female & 146 & 49.7 & 22 & 15.1 & $1.59(0.85-2.99)$ & \\
\hline
\end{tabular}

*Sample varied due to lack of information; ** Prevalence Ratio; ***Wald Test. 
Factors associated with low birth weight in children aged 0 to 36 months at Basic Health Units in a subnormal urban cluster in Northeastern Brazil, Recife, PE, 2015.

\begin{tabular}{|c|c|c|c|c|}
\hline \multirow[t]{2}{*}{ Variable } & PR*Adjusted (Cl95\%) & \multirow[t]{2}{*}{$p^{* *}$} & \multirow{2}{*}{$\frac{\text { PR*Adjusted (Cl95\%) }}{\text { Final model }}$} & \multirow[t]{2}{*}{$p^{* *}$} \\
\hline & Initial model & & & \\
\hline Maternal years of education & & 0.147 & & - \\
\hline$\geq 12$ & 1.0 & & - & \\
\hline$<12$ & $1.76(0.82-3.78)$ & & - & \\
\hline Water supply with domestic canalization & & 0.191 & & - \\
\hline Yes & 1.0 & & - & \\
\hline No & $1.49(0.82-2.73)$ & & - & \\
\hline Sewage disposed into the general system & & 0.588 & & - \\
\hline Yes & 1.0 & & - & \\
\hline No & $1.26(0.55-2.91)$ & & - & \\
\hline Prenatal care attendance & & 0.306 & & - \\
\hline Yes & 1.0 & & - & \\
\hline No & $1.49(0.70-3.17)$ & & - & \\
\hline Alcohol consumption in pregnancy & & $<0.001$ & & $<0.001$ \\
\hline Yes & $2.78(1.51-5.10)$ & & $2.78(1.51-5.10)$ & \\
\hline No & 1.0 & & 1.0 & \\
\hline Child gender & & 0.161 & & - \\
\hline Male & 1.0 & & - & \\
\hline Female & $1.56(0.84-2.91)$ & & - & \\
\hline
\end{tabular}

* Prevalence Ratio; **Wald Test.

actions and orientations during prenatal care. Preventing and avoiding alcohol consumption is an action taken while still in preconception care, as well as the use of medicaments, tabagism, and illegal drugs. 28

Although an association statistically significant between the other variables studied and LBW was not found, the importance of the influence of those factors found in literature stands out. In a crosssectional study with 331,449 births occurred in Spain, Hidalgo-Lopezosa et al.,29 observed great risk of LBW in mothers who were up to 19 years old or over 35 years old, with low educational attainment, single or divorced. Furthermore, other studies also observe increased chance of low weight occurrence in newborns of mothers with low educational attainment. $7,10,17,18$

Evidences also demonstrate association between tabagism (passive tabagism included), and LBW.1214,16 A study conducted with 137 women cared at a reference maternity hospital in Rio de Janeiro identified that pregnant smokers tended to have lowerweight newborns when compared with those who did not smoke. 13

It is likely that the low number of children (294) and the already low occurrence of women who smoke may justify the scarce occurrence of LBW because of this universally recognized risk factor.

Although no statistical associations between LBW and prenatal care have been found in this study, other surveys report a relation between the number of prenatal care appointments and birth weight.25,30 In Feira de Santana (BA), Carvalho et al. 25 concluded that pregnant women with less than six prenatal care visits are 2.94 times more likely to have low-birth-weight babies.Santos et al.30 identified that late-onset prenatal care is related to higher prevalence of newborns with inadequate weight.

It is recognized that some maternal and gestational conditions might be mediated by prenatal care, highlighting not only the appointment quantity, but also the care quality. A case-control study, when analyzing prenatal adequacy and risk factors associated with prematurity and low weight, observed that mothers with inadequate prenatal care had an increased chance of presenting the outcomes. 18 This fact indicates the relevance of effective prenatal care in the prevention of LBW and other unfavorable outcomes.

In the current study, no evaluation about quality nor quantity of maternal alcohol consumption was made, which can be considered a limitation, consi- 
dering differences in the effects on perinatal outcomes according to the amount consumed and the gestational period in which exposure occurred.14 Though, the studied community participated in the process of implementation of basic health actions in Brazil and Latin America almost 40 years ago. Thus, the results of this study may support strategies, from the community itself, which enable to modify this scenario in the country, such as encouraging family planning, considering that alcohol consumption can represent a real problem in all or most slum communities. ${ }^{21}$

It is much likely that the set of factors (unhealthy peridomiciliar and home environments in terms of sanitation; access, frequency, and completion of prenatal care; usage of licit and illicit drugs and other coexisting conditions), which are indicative, yet not conclusive, of the risk of LBW, should remain on the agenda of interventions justified by measures to address the problem, not only in this community but in other spaces of urban poverty in Brazil, other countries and continents.

In the descriptive aspect, a greatly important observation deals with the unfortunate scarcity of information on the distribution of birth weight of Brazilian children in poverty ecosystems, which assume, in slum communities, the most remarkable representation of social vulnerability and its implications to the health-disease process. In addition, there is heterogeneity of situations in slum communities that have not been adequately described or analysed. The study here presented contributes initially as a more generic reference of the dominant health picture in crowded populations in the urban periphe- ries of Brazil, Latin America, and the world. This is still far from being achieved regarding the LBW of other communities in various countries and continents.

In conclusion, this study found that children whose mothers did not drink alcohol during pregnancy were protected from the occurrence of LBW, emphasizing the relevance of maternal habits in newborn health. In addition, it is pertinent to consider the influence of other items of adverse socioeconomic conditions on perinatal outcomes, although not significantly associated with our study. Thus, we highlight the importance of actions aimed at maternal and child health, as well as adequate prenatal care in reducing maternal and child morbidity and mortality. It is also noteworthy that the consumption of alcohol and other licit and illicit drugs remains a public health matter, reinforcing the need for actions and public policies directed to this topic.

\section{Authors' contribution}

Caminha MFC and Batista Filho M - Study design and conception, data acquisition, analysis and interpretation of data, article writing and critical review of relevant intellectual content. Santos CC - Data analysis and interpretation, article writing and critical review of relevant intellectual content. Silva SL- Study design and conception and critical review of relevant intellectual content. Lustosa TF, Farias LCQ and Lima JNA - Data analysis and interpretation and article writing. All authors approved the final version of the manuscript.

\section{References}

1. Santos SPD, Oliveira LMB. Baixo peso ao nascer e sua relação com obesidade e síndrome metabólica na infância e adolescência. Rev Ciênc Méd Biol. 2011; 10 (3): 329-36.

2. Jesus GM, Castelão ES, Vieira TO, Gomes DR, Oliveira VG. Déficit nutricional em crianças de uma cidade de grande porte do interior da Bahia. Ciênc Saúde Coletiva 2014; 19 (5): 1581-8.

3. Quaresma ME, Almeida AC, Méio MD, Lopes JM, Peixoto MV. Factors associated with hospitalization during neonatal period. J Pediatr (Rio J). 2018; 94: 390-8

4. Lima PA, Carvalho M, Costa AC, Moreira ME. Variables associated with extra uterine growth restriction in very low birth weight infants. J Pediatr (Rio J). 2014; 90: 22-7.

5. Kropiwiec MV, Franco SC, Amaral AR. Fatores associados à mortalidade infantil em município com índice de desenvolvimento humano elevado. Rev Paul Pediatr. 2017; 35(4): $391-8$
6. UNICEF (Fundo das Nações Unidas para a Infância). The State of World's Children 2016. A fair chance for every child. [acesso em 17 mar 2018]. Disponível em: $<$ https://www.unicef.org/publications/index_91711.html>.

7. Brasil. Ministério da Saúde. Centro Brasileiro de Análise e Planejamento. Pesquisa Nacional de Demografia e Saúde da Criança e da Mulher - PNDS 2006: relatório final. Brasília: Ministério da Saúde, 2009. [acesso em 17 mar 2018]. Disponível em: http://bvsms.saude.gov.br/bvs/publicacoes/pnds_crianca_mulher.pdf

8. Caminha MFC, Azevedo PTÁCC, Sampaio BB, Acioly VMC, Belo MPM, Lira PIC, Batista Filho M. Aleitamento materno em crianças de 0 a 59 meses no Estado de Pernambuco, Brasil, segundo o peso ao nascer. Ciênc Saúde Coletiva. 2014; 19 (7): 2021-32.

9. Silva ID, Quevedo LDA, Silva RAD, Oliveira SSD, Pinheiro RT. Associação entre abuso de álcool durante a 
gestação e o peso ao nascer. Rev Saúde Pública. 2011; 45: 864-9.

10. Silvestrin S, Silva CH, Hirakata VN, Goldani AA, Silveira PP, Goldani MZ. Maternal education level and low birth weight: a meta-analysis. J Pediatr (Rio J). 2013; 89: 33945 .

11. Metgud CS, Naik VA, Mallapur MD. Factors affecting birth weight of a newborn-a community based study in rural Karnataka, India. PloS one. 2012; 7 (7): e40040.

12. Moreira MÉFH, Silva CL, Freitas RF, Macêdo MS, do Carmo Lessa A. Determinantes socioeconômicos e gestacionais do peso ao nascer de crianças nascidas a termo. Medicina (Ribeirao Preto. Online). 2017; 50 (2): 83-90.

13. Capelli JDCS, Pontes JS, Pereira SEA, Silva AAM, Carmo CND, Boccolini CS, Almeida MFL. Peso ao nascer e fatores associados ao período pré-natal: um estudo transversal em hospital maternidade de referência. Ciênc Saúde Coletiva. 2014; 19: 2063-72.

14. Sbrana M, Grandi C, Brazan M, Junquera N, Nascimento MS, Barbieri MA, Bettiol H, Cardoso VC. Alcohol consumption during pregnancy and perinatal results: a cohort study. São Paulo Med J. 2016; 134 (2): 146-52.

15. Mandal C, Halder D, Jung KH, Chai YG. In Utero Alcohol Exposure and the Alteration of Histone Marks in the Developing Fetus: An Epigenetic Phenomenon of Maternal Drinking. Int J Biol Sci. 2017; 13 (9): 1100-8.

16. Paula Pena JC, Oliveira Pedersoli L, Nunes ML, Santos Freitas JM, Fernandes RAQ. Uso de álcool e tabaco na gestação: influência no peso do recém nascido. Rev SaúdeUNG-Ser. 2017; 11 (1/2): 74-82.

17. Oliveira LL, Gonçalves AC, Costa JSD, Bonilha ALL. Maternal and neonatal factors related to prematurity. Rev Esc Enferm USP. 2016; 50 (3): 382-9.

18. Gonzaga ICA, Santos SLD, Silva ARVD, Campelo V. Atenção pré-natal e fatores de risco associados à prematuridade e baixo peso ao nascer em capital do nordeste brasileiro. Ciênc Saúde Coletiva. 2016; 21(6): 1965-74.

19. Heredia-Olivera K, Munares-García O. Maternal factors associated with low birth weight. Rev Méd Inst Mex Seguro Soc. 2016; 54 (5): 562-7.

20. IBGE (Instituto Brasileiro de Geografia e Estatística). Censo Demográfico 2010. Aglomerados subnormais: informações territoriais. [acesso em: 20 abr.2018]. Disponível em: https://biblioteca.ibge.gov.br/visualizacao/periodicos/552/cd_2010_agsn_if.pdf
21. Ezeh A, Oyebode O, Satterthwaite D, Chen YF, Ndugwa R, Sartori J, Mberu B, Melendez-Torres GJ, Haregu T, Watson SI, Caiaffa W, Capon A, Lilford RJ. The history, geography, and sociology of slums and the health problems of people who live in slums. Lancet. 2017; 389 (10068): 547-58.

22. Caminha MFC. Desenvolvimento infantil em um aglomerado urbano subnormal (favela) do Recife, PE. [Relatório de Pós-Doutorado]. Recife: Instituto de Medicina Integral. Prof. Fernando Figueira - IMIP; 2016.

23. ABEP (Associação Brasileira de Empresas de Pesquisa). 2014. [acesso em 20 maio 2018]. Disponível em: www.abep.org - abep@abep.org.

24. Souza EB. Transição nutricional no Brasil: análise dos principais fatores. Cad UniFOA. 2017; 5 (13): 49-53.

25. Carvalho SS, Coelho JMF, Soares DÂB, Mariola E. Fatores maternos para o nascimento de recém-nascidos com baixo peso e prematuros: estudo caso-controle. Ciência Saúde. 2016; 9 (2): 76-82.

26. Meucci RD, Saavedra JS, Silva ES, Branco MA, Freitas JN, Santos M, Cesar JA. Consumo de bebida alcoólica durante a gestação entre parturientes do extremo sul do Brasil. Rev Bras Saúde Mater Infant. 2017; 17 (4): 653-61.

27. Baptista FH, Rocha KBB, Martinelli JL, Avó LRS, Ferreira RA, Germano CMR, Melo DG. Prevalência e fatores associados ao consumo de álcool durante a gravidez. Rev Bras Saúde Mater Infant. 2017; 17(2): 271-9.

28. Brasil. Ministério da Saúde. Secretaria de Atenção à Saúde. Departamento de Atenção Básica. Cadernos de Atenção Básica. Atenção ao pré-natal de baixo risco. Série A. Normas e Manuais Técnicos. Cadernos de Atenção Básica, no. 32. Brasília-DF. 2012. [acesso em 13 jun 2018]. Disponível em: http://bvsms.saude.gov.br/bvs/publicacoes/cadernos_atencao_basica_32_prenatal.pdf.

29. Hidalgo-Lopezosa P, Jiménez-Ruz A, Carmona-Torres JM, Hidalgo-Maestre M, Rodríguez-Borrego MA, López-Soto PJ. Sociodemographic factors associated with preterm birth and low birth weight: A cross-sectional study. Women Birth. 2019; S1871-5192(18)31693-7.

30. Santos MTMD, Campos T, Silva ACP, Andrade BD, Cândido APC, Oliveira RMS, Nemer ASA, Luquetti SCPD, Pereira Netto M. Fatores relacionados ao peso ao nascer: influência de dados gestacionais. Rev Med Minas Gerais. 2015; 25 (2): 192-8.

Received on January 2, 2019

Final version presented on August 6, 2019

Approved on September 4, 2019 